\title{
Ekmeklik Buğday Çeşitlerinin Verim ve Verim Öğeleri ile Bazı Kalite Özelliklerinin Belirlenmesi
}

\author{
*Seydi AYDOĞAN ${ }^{1}$ \\ Süleyman SOYLU² \\ ${ }^{1}$ Bahri Dağdaş Uluslararası Tarımsal Araştırma Enstitüsü, Konya \\ ${ }^{2}$ Selçuk Üniversitesi Ziraat Fakültesi Tarla Bitkileri Bölümü, Konya \\ *Sorumlu yazar e-posta (Corresponding author; e-mail): seydiaydogan@yahoo.com \\ Geliş Tarihi (Received): 09.02.2017 \\ Kabul Tarihi (Accepted): 25.04.2017
}

\section{Öz}

Bu çalışma, Bahri Dağdaş Uluslararası Tarımsal Araştırma Enstitüsünde 2014-2015 yılı yetiştirme döneminde 14 ekmeklik buğday çeşidiyle kuru yetiştirme koşullarında tesadüf blokları deneme desenine göre 3 tekerrürlü olarak yürütülmüştür. Verim, verim öğeleri ve bazı kalite özellikleri incelenmiştir. Araştırma sonuçlarına göre; bitki boyu 79.50-115 cm, başak uzunluğu $8.87-11.10 \mathrm{~cm}$, başakta tane sayısı 31.20-44.90 adet, başakta tane ağırlığı 1.33-2.07 g, tane verimi 447.42-709.08 kg/da, bin tane ağırlığı 30.90-46.46, hektolitre ağırlığı 73.32-78.35 kg/hl, protein oranı \%11.93-13.44, Zeleny sedimantasyon 26.0-39.50 ml ve tane sertliği(PSI) 41.27-64.82 aralığında değişmiştir. Çeşitler arasında bitki boyu, başakta tane sayısı, bin tane ağırlığı, hektolitre ağırlığı ve Zeleny sedimantasyon bakımından $(p<0.01)$, başak uzunluğu, başakta tane ağırlığı, tane verimi, protein oranı ve tane sertliği bakımından $(p<0.05)$ önemli farklııklar bulunmuştur. En yüksek bitki boyu, başak uzunluğu, başakta tane sayısı, başakta tane ağırlığı ve tane verimi sırasıyla Demir-2000, Konya-2002, Gün-91, Bozkır ve Karahan-99 çeşitlerinden elde edilmiştir.

Anahtar Kelimeler: Ekmeklik buğday, verim, kalite

\section{Determination of Yield, Yield Components and Some Quality Properties of Bread Wheat Varieties}

\begin{abstract}
This research was carried out with 14 bread wheat variety under rainfed conditions during 2014-2015 growing season according to randomized block designed with three replications in Bahri Dağdaş International Agricultural Research Institue. Yield, yield components and some quality characteristics were examined. According to the results of the research; Plant height $79.50-115 \mathrm{~cm}$, spike length $8.87-11.10 \mathrm{~cm}$, number of grains per spike 31.20-44.90 pieces, grain weight per spike $1.33-2.07 \mathrm{~g}$, grain yield $447.42-709.08 \mathrm{~kg} / \mathrm{da}$, thousand kernel weight $30.90-46.46$, test weight $73.32-78.35 \mathrm{~kg} / \mathrm{hl}, 11.93-13.44 \%$ protein content, Zeleny sedimentation $26.0-39.50 \mathrm{ml}$ and grain hardness(PSI) ranged between 41.27-64.82. Significant differences were found between the varieties in terms of plant height, number of grains per spike, thousand kernel weight, test weight, Zeleny sedimentation $(p<0.01)$, spike lenght, grain weight per spike, grain yield, protein content and grain hardness $(p<0.05)$. The highest plant height, highest spike length, highest number of grains per spike, highest grain weight per spike and highest grain yield were obtained from Demir-2000, Konya-2002, Gün-91, Bozkır and Karahan-99 varieties respectively.
\end{abstract}

Keywords: Bread wheat, yield, quality

\section{Giriş}

uğday en önemli beslenme kaynağı ve stratejik bir ürün olma özelliğinden dolayı gıda sektörünün vazgeçilmez ana ürünüdür. Günümüzde 6 milyar olan dünya nüfusunun 2050 yılında 9-10 milyar olması beklenmektedir.

Dünya üzerinde yaşayan insanların enerji gereksinimi, beslenmesi için gerekli olan kalori ve proteinin önemli bir kısmını hububat ürünleri ile karşılamaktadır. Dünyada 2015 yılında 218.40 milyon hektar alanda buğday ekimi 
yapılmış 713.10 milyon ton buğday üretimi gerçekleşmiş, ülkemizde 7.77 milyon hektar alanda buğday ekimi yapılmış olup üretim ise 22.6 milyon ton olmuştur. Dünyada tüketim amaçlı olarak kullanılan buğdayların \%5'lik kısmını durum ve spelta buğdayları, \%95'ini ise ekmeklik buğdaylar oluşturmaktadır. Ülkemizde ekmeklik buğdayın ekim alanı içindeki payı yaklaşık olarak \%83 civarındadır (Anonim 2013). Ülkemiz buğday ekim alanı bakımından dünyada 9. sırada üretimde ise 11. sırada yer almıştır (Anonim 2015). Konya ilinin buğday ekim alanı 2014-2015 yetiştirme döneminde 760.000 hektar civarında gerçekleştirildiği, üretimi 2.6-2.8 milyon ton ve tane veriminin $335 \mathrm{~kg} / \mathrm{da}$ olduğu hesap edilmiştir (Anonim 2015). Çevresel stres faktörlerinden kuraklık, dünyada ve ülkemizde yağışa bağımlı tarım alanlarının büyük bir bölümünde bitkisel üretimi kısıtlayan önemli bir faktördür. Türkiye'de yetiştirilen buğdayın \%80'ininin büyük bir kısmı kuru tarım yapılan alanlarda yetiştirilmekte, büyük bir bölümünü ise Orta Anadolu ve Geçit Bölgeleri oluşturmaktadır. Tane verimini etkileyen faktörlerin başında yağış miktarı ve yağışın yetişme periyodu içindeki dağılımı kuraklığın şiddetine ve dağılımına bağlı olarak \%40-65'lere varan verim kayıplarına neden olabilmektedir (Öztürk 1999). Dünya çapında son yıllarda meydana gelen iklim değişmeleri düşünüldüğünde yüksek tane verimi, kaliteli, hastalık ve zararlılara dayanıklı buğday çeşitlerinin geliştirilmesi, ıslah çalışmalarının önemli hedeflerinden biri olmuştur.

$\mathrm{Bu}$ çalışma Orta Anadolu Bölgesi'nde yaygın olarak ekilen 14 ekmeklik buğday çeşidinin tane verimi, bazı verim unsurları ve kalite özellikleri incelenmiş, çeşitlerin verim ve kalite performanslarının belirlenmesi ve bölge çiftçisine yeni çeşitlerin genel durumları hakkında bilgi sağlanması bu çalışmanın amaçları arasında yer almıştır.

\section{Materyal ve Yöntem}

Bu çalışma 2014-2015yetiştirme döneminde Bahri Dağdaş Uluslararası Tarımsal Araştırma Enstitüsünde kuru koşullarda 14 ekmeklik buğday çeşidiyle (Gün-91, Sönmez-2001, Bezostaja-1, Tosunbey, Pehlivan, Demir-2000, Bayraktar-2000, Gerek-79, Karahan-99, Yunus, Ahmetağa, Konya-2002, Bozkır ve Eraybey) tesadüf blokları deneme desenine göre üç tekerrürlü olarak yürütülmüştür. Ekim kuru koşullarda 550 adet $/ \mathrm{m}^{2}$ tohum olacak şekilde ve parsel boyutları $8.4 \mathrm{~m}^{2}, 6$ sıra ve sıra arası $20 \mathrm{~cm}$ olarak parsel mibzeriyle ekim yapılmıştır. Ekimle birlikte $3.5 \mathrm{~kg} / \mathrm{da} \mathrm{N}$ ve $6.9 \mathrm{~kg} / \mathrm{da} \mathrm{P}_{2} \mathrm{O}_{5}$ ve üst gübre olarak $4 \mathrm{~kg} / \mathrm{da} \mathrm{N}$ verilmiştir. Yetiştirme döneminde Konya merkez lokasyonunda toplam 398.70 mm yağış alınmıştır. Araştırmada çeşitlerin başak uzunluğu, bitki boyu, başakta tane sayısı, başakta tane ağırlığı, tane verimi (Yürür ve ark. 1981), bin tane ve hektolitre ağırlığı (Elgün ve ark. 2001), protein oranı \%, AOAC 992.23 (Anonymous 2009) metoduna göre, tane sertliği (PSI) Near infrared reflektans spektroskopi cihazı AACC 39-10 metoduna göre (Anonymous 2000) analiz edilmiştir. Zeleny sedimantasyon AACC 56-61A (Anonymous 2000)'e göre analiz edilmiştir. Denemelerden elde edilen sonuçların değerlendirilmesinde, varyans analizi (JMP11) istatistik analiz programına göre yapılmış ve farklılıkları önemli olan özelliklerin ortalama değerleri AÖF (\%5) testine göre gruplandırılmıştır (Anonim 2014).

\section{Bulgular ve Tartışma}

\section{Bitki Boyu ve Başak Uzunluğu}

Ekmeklik buğday çeşidinin ortalama bitki boyu ve başak uzunluğuna ait sonuçlar Çizelge 2'de verilmiştir. Çeşitler arasındaki farklılık bitki boyunda $(p<0.01)$ ve başak uzunluğunda ise $(p<0.05)$ seviyesinde önemli bulunmuştur (Çizelge 1). Araştırmada kuru koşullarda yetiştirilen çeşitlerin bitki boyu 79.50 ile $115 \mathrm{~cm}$ arasında değişmiştir. Deneme ortalaması 92.29 cm olup, en yüksek bitki boyu Demir-2000 ve en düşük bitki boyu değeri ise Pehlivan çeşidinden elde edilmiştir. Eraybey, Bozkır ve Karahan-99 çeşitleri deneme ortalaması üzerinde bitki boyuna sahip olmuştur. Yapılan benzer çalışmalarda ekmeklik buğdayda bitki boyunun, farklı gelişme dönemlerinde görülen kuraklık stresi altında azalma gösterdiği ve bu azalmanın kuraklığın geliş zamanı ve şiddetine göre varyasyon gösterdiği belirtilmiştir (Subhani and Ghowdhvy 2000; Kimurto et al. 2004; Shamsi et al. 2010). Araştırmada kuru koşullarda çeşitlerin başak uzunluğu 8.87 ile $11.10 \mathrm{~cm}$ arasında değişmiş, deneme ortalaması $9.75 \mathrm{~cm}$ olmuştur. En yüksek başak uzunluğu değeri Gün-91 ve en düşük değer ise Bayraktar-2000 çeşidinden elde edilmiştir. Genel olarak incelediğimizde Konya-2002, Karahan-99, Demir-2000 ve Ahmetağa çeşitlerinde deneme ortalaması üzerinde başak uzunluğu elde edilmiştir (Çizelge 2). Tunca (2012), 2010-2011 yetiştirme döneminde 16 ekmeklik buğday çeşidinin başak uzunluğunu 7.7-9.7 cm arasında değiştiğini tespit etmiştir. Yapılan çalışmada başak uzunluğunun 2014-2015 yılı yağış miktarının fazla olmasından dolayı diğer çalışmalara göre daha uzun olduğu tespit edilmiştir. 
Aydoğan ve Soylu "Ekmeklik Buğday Çeşitlerinin Verim ve Verim Öğeleri ile Bazı Kalite Özelliklerinin Belirlenmesi"

Çizelge 1. Ekmeklik buğday çeşitlerinde incelenen özelliklere ilişkin varyans analiz sonuçları Table 1. Variance analyasis results of the traits in bread wheat varieties

\begin{tabular}{|c|c|c|c|}
\hline Varyasyon Kaynağı & Kareler Toplamı & F Değeri & $P$ \\
\hline Bitki Boyu (cm) & 2780.6071 & 17.0889 & $<.0001^{* *}$ \\
\hline Başak Uzunluğu (cm) & 13.106061 & 5.4082 & 0.0023 \\
\hline Başakta Tane Sayısı (adet) & 502.24714 & 12.0249 & $<.0001^{* *}$ \\
\hline Başakta Tane Ağırlığı (g) & 1.3004499 & 7.4406 & $0.0005^{\star}$ \\
\hline Tane Verimi (kg/da) & 835048.67 & 6.1635 & $0.0012^{*}$ \\
\hline Bin tane Ağırlığı (g) & 733.73034 & 15.2731 & $<.0001^{* *}$ \\
\hline Hektolitre Ağırlığı (kg/hl) & 45.713182 & 12.1896 & $<.0001^{* *}$ \\
\hline Protein Oranı (\%) & 5.2900179 & 5.1763 & $0.0028^{*}$ \\
\hline Zeleny Sedimantasyon (ml) & 432.42857 & 20.1800 & $<.0001^{* *}$ \\
\hline Tane Sertliği (PSI) & 1867.4123 & 14.3103 & $<.0001^{\star *}$ \\
\hline
\end{tabular}

*,**:Sırasıyla 0.05 ve 0.01 düzeyinde önemli

***: Significant at $p<0.05$ and 0.01 , respectively

Çizelge 2. Bitki boyu, başak uzunluğu, başakta tane sayısı, başakta tane ağılığı ve tane verimi ortalama değerleri

Table 2. Mean values of plant height, spike length, grain number per spike, grain weight per spike and grain yield

\begin{tabular}{|c|c|c|c|c|c|}
\hline Çeşitler & $\begin{array}{l}\text { Bitki Boyu } \\
(\mathrm{cm})\end{array}$ & $\begin{array}{c}\text { Başak Uzunluğu } \\
(\mathrm{cm})\end{array}$ & $\begin{array}{l}\text { Başakta Tane } \\
\text { Sayısı (adet) }\end{array}$ & $\begin{array}{l}\text { Başakta Tane } \\
\text { Ağırlığı (g) }\end{array}$ & $\begin{array}{c}\text { Tane Verimi } \\
\text { (kg/da) }\end{array}$ \\
\hline Ahmetağa & $81.5 \mathrm{de}$ & 9.93 bcde & $40.15 \mathrm{bcd}$ & 1.64 cdef & $655.58 a b$ \\
\hline Bayraktar-2000 & 86.5 de & $8.87 \mathrm{f}$ & 35.60 ef & $1.49 \mathrm{efg}$ & $647.00 \mathrm{ab}$ \\
\hline Bezostaja-1 & $90.0 \mathrm{~cd}$ & 9.30 ef & $31.20 \mathrm{f}$ & 1.54 efg & $518.75 a b$ \\
\hline Bozkır & $107 a b$ & 9.59 def & $42.10 a b$ & $2.07 \mathrm{a}$ & $579.42 \mathrm{de}$ \\
\hline Demir-2000 & $115 a$ & $10.48 \mathrm{abcd}$ & $40.00 \mathrm{abcd}$ & $1.81 \mathrm{bcd}$ & $447.42 \mathrm{~b}$ \\
\hline Eraybey & $108.2 a b$ & 9.09 ef & 35.45 bcde & $1.69 \mathrm{cde}$ & $658.58 a b$ \\
\hline Gerek-79 & $89.00 \mathrm{de}$ & 9.64 def & $33.45 \mathrm{cde}$ & 1.68 cdef & $449.00 \mathrm{bc}$ \\
\hline Gün-91 & $90.75 \mathrm{~cd}$ & $11.10 \mathrm{a}$ & $44.90 \mathrm{a}$ & 1.47 efg & $550.42 a b$ \\
\hline Karahan-99 & 99.75 bc & $10.58 a b c$ & $32.60 \mathrm{de}$ & $1.33 \mathrm{~g}$ & $709.08 \mathrm{a}$ \\
\hline Konya-2002 & $81.50 \mathrm{de}$ & $10.69 a b$ & $38.30 \mathrm{ab}$ & $1.97 a b$ & $630.58 a b$ \\
\hline Pehlivan & $79.50 \mathrm{e}$ & 9.02 ef & 39.10 abcde & $1.86 \mathrm{abc}$ & $593.83 a b$ \\
\hline Sönmez-2001 & $87.00 \mathrm{de}$ & 9.72 cdef & 36.80 abcde & 1.59 def & $521.50 a b$ \\
\hline Tosunbey & $86.75 \mathrm{de}$ & 9.58 def & $40.80 \mathrm{abc}$ & $1.44 \mathrm{fg}$ & $589.42 a b$ \\
\hline Yunus & 89.50 cde & $8.99 \mathrm{f}$ & $40.10 \mathrm{abcd}$ & $1.96 a b$ & $626.58 a b$ \\
\hline Ortalama & 92.29 & 9.75 & 37.9 & 1.68 & 584.08 \\
\hline $\mathrm{DK}_{(\%)}$ & 3.04 & 4.41 & 4.58 & 7.52 & 8.15 \\
\hline AÖF $_{(0.05)}$ & 2.16 & 0.92 & 3.86 & 0.23 & 110 \\
\hline
\end{tabular}

*: Aynı harfle gösterilen ortalamalar arasındaki farklar $P<0.05$ düzeyinde önemsizdir

*: Differences between the means followed by the same letter are not significant at $P<0.05$ level

\section{Başakta Tane Sayısı ve Başakta Tane Ağırlığı}

Ekmeklik buğday çeşitlerinin ortalama başakta tane sayısı ve başakta tane ağırlı̆ı̆ına ait değerler Çizelge 3'de verilmiştir. Çeşitler arasındaki farklılık başakta tane sayısında $(p<0.01)$ ve başakta tane ağırlığında $(p<0.05)$ seviyesinde önemli bulunmuştur (Çizelge
1). Araştırmada kuru koşullarda yetiştirilen çeşitlerin başakta tane sayısı 31.20 ile 44.90 adet arasında değişmiş, deneme ortalaması 37.90 adet olarak belirlenmiştir. En yüksek değer Gün-91 ve en düşük değer ise Bezostaja-1 çeşidinde elde edilmiştir. Çeşitleri genel olarak incelediğimizde Bozkır, Tosunbey, Ahmetağa, Yunus, Demir-2000, 
Aydoğan and Soylu "Determination of Yield, Yield Components and Some Quality Properties of Bread Wheat Varieties"

Çizelge 3. Bin tane ağırlığı, hektolitre ağırlığı, Protein oranı, Zeleny sedimantasyon ve Tane sertliği ortalama değerleri

Table 3. Mean values of thousand kernel weight, test weight, protein content, Zeleny sedimentation and grain hardness (PSI)

\begin{tabular}{|c|c|c|c|c|c|}
\hline Çeşitler & $\begin{array}{c}\text { Bin Tane } \\
\text { Ağırlığı (g) }\end{array}$ & $\begin{array}{c}\text { Hektolitre } \\
\text { Ağırlığı }(\mathrm{kg} / \mathrm{hl}) \\
\end{array}$ & $\begin{array}{c}\text { Protein } \\
\text { Oranı (\%) } \\
\end{array}$ & $\begin{array}{l}\text { Zeleny Sedimantasyon } \\
(\mathrm{ml})\end{array}$ & $\begin{array}{c}\text { Tane Sertliği } \\
\text { (PSI) }\end{array}$ \\
\hline Ahmetağa & 34.44 def & $76.00 \mathrm{c}$ & $12.14 \mathrm{fg}$ & $36.0 \mathrm{bc}$ & $46.40 \mathrm{de}$ \\
\hline Bayraktar-2000 & $36.54 \mathrm{cde}$ & $75.57 \mathrm{c}$ & 12.36 defg & $26.0 \mathrm{~h}$ & $64.82 \mathrm{a}$ \\
\hline Bezostaja-1 & $42.84 a b$ & $78.35 a$ & $12.74 \mathrm{cdef}$ & $37.5 \mathrm{ab}$ & $50.61 \mathrm{~cd}$ \\
\hline Bozkır & 36.34 cde & $76.60 \mathrm{bc}$ & $13.44 \mathrm{a}$ & $37.5 a b$ & $60.67 \mathrm{ab}$ \\
\hline Demir-2000 & $42.86 \mathrm{ab}$ & $77.61 \mathrm{ab}$ & $12.93 \mathrm{abcd}$ & $34.5 \mathrm{~cd}$ & $47.61 \mathrm{de}$ \\
\hline Eraybey & $37.46 \mathrm{~cd}$ & $77.92 \mathrm{a}$ & 12.26 efg & $39.5 \mathrm{a}$ & $56.60 \mathrm{bc}$ \\
\hline Gerek-79 & $30.90 \mathrm{f}$ & $73.32 \mathrm{~d}$ & $13.37 \mathrm{ab}$ & $26.0 \mathrm{~h}$ & $63.67 \mathrm{a}$ \\
\hline Gün-91 & 33.24 ef & $77.29 a b$ & $11.93 \mathrm{~g}$ & $31.0 \mathrm{efg}$ & $42.91 \mathrm{~h}$ \\
\hline Karahan-99 & 32.68 ef & $77.26 \mathrm{ab}$ & $13.02 \mathrm{abc}$ & $34.0 \mathrm{~cd}$ & $60.29 a b$ \\
\hline Konya-2002 & $39.82 \mathrm{bc}$ & $77.70 a b$ & 12.52 cdefg & $35.0 \mathrm{bcd}$ & $45.31 \mathrm{de}$ \\
\hline Pehlivan & $45.88 \mathrm{a}$ & $77.56 \mathrm{ab}$ & 12.42 cdefg & $30.0 \mathrm{~g}$ & $44.01 \mathrm{de}$ \\
\hline Sönmez-2001 & $44.20 \mathrm{a}$ & $77.85 a$ & 12.43 cdefg & $30.5 \mathrm{fg}$ & $41.27 \mathrm{e}$ \\
\hline Tosunbey & $32.84 \mathrm{~cd}$ & $75.90 \mathrm{c}$ & 12.78 bcde & 33.0 def & $45.64 \mathrm{de}$ \\
\hline Yunus & $46.46 \mathrm{a}$ & $77.61 \mathrm{ab}$ & 12.26 efg & 33.5 cde & $42.73 \mathrm{e}$ \\
\hline Ortalama & 38.32 & 76.9 & 12.61 & 33.1 & 50.89 \\
\hline $\mathrm{DK}_{(\%)}$ & 5.5 & 4.69 & 2.33 & 3.87 & 6.32 \\
\hline AÖF $_{(0.05)}$ & 1.9 & 0.9 & 0.28 & 2.28 & 6.1 \\
\hline
\end{tabular}

*: Aynı harfle gösterilen ortalamalar arasındaki farklar $\mathrm{P}<0.05$ düzeyinde önemsizdir

*: Differences between the means followed by the same letter are not significant at $P<0.05$ level

Pehlivan ve Konya-2002 çeşitlerinde deneme ortalaması üzerinde başakta tane sayısı elde edilmiştir(Çizelge 2). Araştırmada kuru koşullarda çeşitlerin başakta tane ağırlığı 1.33 ile $2.07 \mathrm{~g}$ arasında değişmiş, deneme ortalaması $1.68 \mathrm{~g}$ olmuştur. Başakta tane ağırlığı bakımından en yüksek değer Bozkır ve en düşük değer ise Karahan-99 çeşidinde elde edilmiştir. Genel olarak incelediğimizde Konya-2002, Yunus, Pehlivan, Demir-2000 ve Eraybey çeşitlerinde deneme ortalaması üzerinde başakta tane ağırığı elde edilmiştir (Çizelge 2). Tunca (2012), Eskişehir yöresinde 2010-2011 yetiştirme döneminde kuru koşullarda ekmeklik buğday çeşitleri ile yaptığı çalışmada, verim unsurlarından başaktaki tane ağırlığının 0.5-1.4 g arasında değiştiğini belirlemiştir. Dencic et al. (2000), 30 ekmeklik buğday çeşidi ve değişik ülkelerden topladıkları 21 yerel popülasyonun optimum ve kurak koşullarda tane verimi, verim unsurları ve morfolojik özelliklerini değerlendirdikleri bir çalışmada, başakta tane ağırlığı, bin tane ağırlığı ve tane veriminin, kuraklığa bitki boyundan ve başaktaki başakcık sayısından daha hassas olduğunu tespit etmişlerdir.

\section{Tane Verimi ve Bin Tane Ağırlığı}

Ekmeklik buğday çeşitlerinin ortalama tane verimi ve bin tane ağırlığına ait değerler Çizelge 4'de verilmiştir. Çeşitler arasındaki farklılık tane verimi bakımından $(p<0.05)$ ve bin tane ağırlığında $(p<0.01)$ seviyesinde önemli bulunmuştur (Çizelge 1). Araştırmada kuru koşullarda yetiştirilen çeşitlerin tane verimi 447.42 ile 709.08 kg/da arasında değişmiş, deneme ortalaması 584.08 kg/da, en yüksek tane verimi değeri Karahan-99 ve en az değer ise Gerek-79 çeşidinden elde edilmiştir. Genel olarak incelediğimizde Bozkır, Eraybey, Ahmetağa, Bayraktar-2000, Konya-2002, Yunus ve Pehlivan çeşitlerinde deneme ortalaması üzerinde tane verimi elde edilmiştir (Çizelge 2). Denemede yer alan çeşitlerin tane verimlerinin yüksek olması yağış miktarının uzun yıllar ortalamalarına göre yüksek olmasından kaynaklanmıştır. Aydoğan ve ark. (2010), kuru koşullarda 18 ekmeklik buğday çeşidiyle yapmış oldukları bir çalışmada tane veriminin 331.85 ile $749.07 \mathrm{~kg} / \mathrm{da}$ arasında değiştiğini, ortalama tane veriminin $449.35 \mathrm{~kg} /$ da olduğunu belirtmişlerdir. Yine aynı çalışmada en yüksek tane verimi değerinin $749.07 \mathrm{~kg} / \mathrm{da}$ ile Soyer-02 ve en düşük değerin ise 331.85 
$\mathrm{kg} / \mathrm{da}$ ile Altay-2000 çeşidinden elde edildiğini tespit etmişlerdir. Birim alandan yüksek verim ve kaliteli ürün elde edebilmek için uygun yetiştirme şartları ve tekniklerinin uygulanması yanında verim potansiyeli optimum olan çeşitlerin tercih edilmesi gerekmektedir. Buğday tanesinin tohumluk ve un verimi hakkında bilgi veren bin tane ağırlığı 30.90 ile $46.46 \mathrm{~g}$ arasında değişmiştir. Deneme ortalaması 38.32 $\mathrm{g}$ olup, en yüksek değer Yunus ve en düşük değer ise Gerek-79 çeşitlerinde elde edilmiştir. Çeşitleri genel olarak incelediğimizde Pehlivan, Sönmez-2001, Demir-2000, Bezostaja-1 ve Konya-2002 çeşitlerinde deneme ortalaması üzerinde bin tane ağırlığı elde edilmiştir (Çizelge 3). Aydemir ve ark. (2001), Orta Anadolu koşullarında Karahan-99, Gerek-79 ve Dağdaş-94 çeşitleri (31-34, 30-36 ve 34-40 g) arasında bin tane ağırlıklarının değiştiğini tespit etmişlerdir. Aydoğan ve ark. (2007), kuru koşullarda 2005-2006 yılları arasında yapmış oldukları bir çalışmada Konya-2002, Gerek-79, Bezostaja-1 ve Dağdaş-94 çeşitlerinde sırasıyla $30.32,28.36,31.06$ ve $36.96 \mathrm{~g}$ bin tane ağırlığı elde etmişlerdir.

\section{Hektolitre Ağırlığı ve Protein Oranı}

Ekmeklik buğday çeşitlerinin ortalama hektolitre ağırlığı ve protein oranına ait değerler Çizelge 5'de verilmiştir. Çeşitler arasındaki farklılık hektolitre ağırığında $(p<0.01)$ ve protein oranında $(p<0.05)$ seviyesinde önemli bulunmuştur (Çizelge 1). Araştırmada kuru koşullarda çeşitlerin hektolitre ağırlığı 73.32 ile $78.35 \mathrm{~kg} / \mathrm{hl}$ arasında değişmiş, deneme ortalaması $76.90 \mathrm{~kg} / \mathrm{hl}$ olmuş, en yüksek değerler Bezostaja-1, Eraybey ve Sönmez-2001 çeşitlerinde en düşük değer ise Gerek-79 çeşidinde elde edilmiştir. Çeşitleri genel olarak incelediğimizde Eraybey, Sönmez-2001, Konya-2002, Yunus, Demir-2000, Pehlivan ve Gerek-79 çeşitlerinde deneme ortalaması üzerinde hektolitre ağırlığı elde edilmiştir (Çizelge 3). Araştırmada kuru koşullarda çeşitlerin protein oranı \%11.93 ile \%13.44 arasında değişmiş, deneme ortalaması \%12.61 olmuştur. En yüksek protein oranı Bozkır ve en düşük değer ise Gün-91 çeşidinde elde edilmiştir. Çeşitleri genel olarak incelediğimizde Bozkır, Gerek-79, Karahan-99, Demir-2000, Tosunbey ve Bezostaja-1 çeşitlerinde deneme ortalaması üzerinde protein oranı belirlenmiştir (Çizelge 3). Aydemir ve ark. (2001), yapmış oldukları bir çalışmada ekmeklik buğday çeşitlerinde protein oranlarının (Karahan-99 çeşidinde \%11-13, Gerek-79'da \%10-12 ve Dağdaş-94'de \%11-12) arasında değiştiğini tespit etmişlerdir. Şahin ve ark. (2008), kuru koşullarda yetiştirilen ekmeklik buğdaylarda protein oranının \%12.62-14.16, sulu koşullarda ise \%11.53-13.85 arasında değiştiğini belirlemişlerdir. Ercan ve Bildik (1993), azotlu gübre uygulamasının ekmeklik buğday kalitesine etkisini inceledikleri bir araştırmada azotlu gübre dozu artıkça protein miktarının, camsılık oranının arttığını belirlemişlerdir.

\section{Zeleny Sedimantasyon ve Tane Sertliği}

Ekmeklik buğday çeşitlerinin ortalama Zeleny sedimantasyon değeri ve tane sertliğine ait veriler Çizelge 3'de verilmiştir. Çeşitler arasındaki farklıık Zeleny sedimantasyon değerinde $(p<0.01)$ ve tane sertliğinde $(p<0.01)$ seviyesinde önemli bulunmuştur (Çizelge 1). Zeleny sedimantasyon protein kalitesinin bir

Çizelge 4. İncelenen özellikler arasındaki korelasyon katsayıları

Table 4. The correlation coefficients between the examined traits

\begin{tabular}{lccccccccc}
\hline Özellikler & $\begin{array}{c}\text { Bitki } \\
\text { boyu }\end{array}$ & $\begin{array}{c}\text { Başak } \\
\text { Uzunluğu }\end{array}$ & $\begin{array}{c}\text { Başakta } \\
\text { Tane } \\
\text { Sayısı }\end{array}$ & $\begin{array}{c}\text { Başaktaki } \\
\text { Tane } \\
\text { Ağırlığı }\end{array}$ & $\begin{array}{c}\text { Tane } \\
\text { Verimi }\end{array}$ & $\begin{array}{c}\text { Bin tane } \\
\text { Ağr }\end{array}$ & $\begin{array}{c}\text { Hektolitre } \\
\text { Ağr. }\end{array}$ & $\begin{array}{c}\text { Protein } \\
\text { Oranı }\end{array}$ & $\begin{array}{c}\text { Zeleny } \\
\text { Sed. }\end{array}$ \\
\hline Başak Uz. & 0.2316 & & & & & & & & \\
Başakta T. S & -0.1269 & 0.1684 & & & & & & & \\
Tane Ağır. & 0.1044 & -0.1093 & $0.6216^{*}$ & & & & & & \\
Tane Verimi & -0.3208 & -0.2961 & 0.0298 & 0.2055 & & & & \\
Bin tane & 0.1043 & -0.3505 & -0.2536 & $0.4512^{*}$ & $0.5788^{*}$ & & & \\
Hektolitre & 0.3063 & 0.0924 & -0.3700 & 0.1110 & $0.3823^{*}$ & $0.6173^{*}$ & & \\
Protein & 0.2193 & -0.0155 & 0.1500 & 0.1316 & $-0.4005^{*}$ & -0.2244 & -0.3004 & \\
Zeleny Sed. & 0.3023 & 0.1110 & 0.1497 & 0.2556 & 0.3027 & 0.1173 & $0.5655^{*}$ & 0.0334 \\
Sertlik Değeri & 0.0933 & -0.1942 & 0.0803 & -0.1123 & $-0.5974^{*}$ & $-0.5013^{*}$ & $-0.4885^{*}$ & $0.5042^{*}$ & -0.1277 \\
\hline
\end{tabular}

Başakta T.S: Başakta Tane sayısı, Başak Uz: Başak Uzunluğu, Zeleny Sed: Zeleny Sedimantasyon

Başakta T.S: Grai number per spike, Başak Uz: Spike length, Zeleny Sed: Zeleny sedimentation

${ }^{*}, * *$ :Sırasıyla 0.05 ve 0.01 düzeyinde önemli

***: Significant at $p<0.05$ and 0.01 , respectively 
Aydoğan and Soylu "Determination of Yield, Yield Components and Some Quality Properties of Bread Wheat Varieties"

Çizelge 5. ane verimi ile incelenen özellikler arasındaki regresyon eşitlikleri

Table 5. The regression equations between grain yield and examined traits

\begin{tabular}{|c|c|c|}
\hline İncelenen Özellikler & Regresyon Eşitliği & $R^{2}$ \\
\hline Hektolitre Ağırlığı & 74.806064+0.0027499*T.Verim* & 0.146169 \\
\hline Bin tane Ağırlığı & $25.844093+0.0164028^{*} \mathrm{~T}$. Verim* & 0.334986 \\
\hline Protein Oranı & $13.44468-0.0010959^{*} \mathrm{~T}$. Verim* & 0.160374 \\
\hline Sertlik Değeri & $71.485229-0.0270713^{*}$ T. Verim* & 0.356943 \\
\hline
\end{tabular}

${ }^{*},{ }^{* *}$ :Sırasıyla 0.05 ve 0.01 düzeyinde önemli

***: Significant at $p<0.05$ and 0.01 , respectively

göstergesi olarak kabul edilen ve sanayiciler tarafından yaygın olarak kullanılan bir özelliktir. Araştırmada kuru koşullarda çeşitlerin Zeleny sedimantasyon değeri 26.0 ile $39.5 \mathrm{ml}$ arasında değişmiş, deneme ortalaması $33.1 \mathrm{ml}$ olup, en yüksek değer Eraybey ve en düşük değer ise Bayraktar-2000 ve Gerek-79 çeşitlerinden elde edilmiştir. Çeşitleri genel olarak incelediğimizde Bozkır, Bezostaja-1, Ahmetağa ve Konya-2002 çeşitlerinde deneme ortalaması üzerinde Zeleny sedimantasyon elde edilmiştir (Çizelge 3 ). Aydoğan ve ark. (2013), kuru koşullarda 21 ekmeklik buğday çeşidinin Zeleny sedimantasyon değerinin 19.5-62.5 ml arasında değiştiğini, en yüksek değerlerin Bağcı-2002 $62.5 \mathrm{ml}$, Gün-91 $60.50 \mathrm{ml}$, Karahan-99 57.50 $\mathrm{ml}$, Eraybey $55.50 \mathrm{ml}$ ve Soyer-02 51.50 $\mathrm{ml}$ elde edildiğini belirlemişlerdir. Özturk ve Aydın (2004), farklı yetiştirme koşulları altında sedimantasyon değerlerini; sulu şartlarda 32.2 $\mathrm{ml}$, kuru şartlarda $35.7 \mathrm{ml}$, erken dönemde su stresi şartlarında $34.0 \mathrm{ml}$, geç dönem su stresi şartlarında $35.0 \mathrm{ml}$ ve sürekli su stresi şartlarında ise $37.5 \mathrm{ml}$ olarak tespit etmişlerdir. Sertlik (PSI) cinsinden ölçülmüş olup 100'e yakın olan değerler tane yumuşaklığını ifade etmektedir. Araştırmada kuru koşullarda çeşitlerin sertlik değeri (PSI) 41.27 ile 64.82 arasında değişmiş, deneme ortalaması ise (PSI) 50.89 olup, Sönmez-2001 çeşidi en sert grupta ve Bayraktar-2000 çeşidi ise yumuşak grupta yer almıştır (Çizelge 3). Şahin ve ark. (2013), 2011-2012 yetiştirme döneminde 314 genotipte yapmış oldukları bir çalışmada sertlik değerinin 27 ile 73 arasında değiştiğini, ortalama sertlik değerinin (PSI) 52.5 olduğunu tespit etmişlerdir.

Bu çalışmada incelenen özellikler arasındaki ilişkileri tespit etmek için korelasyon analizi yapılmıştır. Başakta tane sayısı ile başaktaki tane ağırlığı $\left(0.6216^{*}\right)$, bin tane ağırlığı ile başakta tane ağırlığı $\left(0.4512^{*}\right)$, hektolitre ağırlığı ile bin tane ağırlığı $\left(0.6173^{*}\right)$,hektolitre ağırlığı ile tane verimi $\left(0.3823^{*}\right)$, Zeleny sedimantasyon ve hektolitre ağırlığı $\left(0.5655^{*}\right)$ ve protein oranı ve sertlik değerleri arasında $\left(0.5042^{*}\right)$ önemli pozitif ilişki tespit edilmiştir. Tane verimi; protein oranı $\left(-0.4005^{*}\right)$ ve sertlik arasında $\left(-0.5974^{*}\right)$, bin tane ağırlığı ile sertlik değeri $\left(-0.5013^{*}\right)$ ve hektolitre ağırlığı ile sertlik değeri arasında(-0.4885*) negatif önemli ilişki tespit edilmiştir(Çizelge 4). Tane verimi İle başakta tane ağırlığı, bin tane ağırığı, protein oranı ve tane sertliği arasında korelasyon $(p<0.05)$ seviyesinde önemli bulunmuştur. Tane verimi ile önemli korelasyon gösteren özellikler arasındaki regresyon eşitlikleri ve $R^{2}$ değerleri (Çizelge 5) verilmiştir.

\section{Sonuç}

Bu çalışmada 14 ekmeklik buğday çeşidinin kuru koşullarda verim, verim unsurları ve bazı kalite özellikleri tespit edilmeye çalışıımıştır. Elde edilen verilerle yapılan varyans analizleri sonucunda incelenen tüm özellikler ve yetiştirme koşullarının çeşitler arasındaki farklılıkları istatistiki açıdan önemli bulunmuştur. Çalışma sonucunda; Bitki boyu bakımından Demir-2000, başak uzunluğunda Konya-2002, başakta tane sayısında Gün-91, başakta tane ağırlığında Bozkır, tane veriminde Karahan-99, bin tane ağılığında Pehlivan ve Sönmez-2000, hektolitre ağırlığında Eraybey, Bayraktar-2000 ve Sönmez-2000, protein oranında Bozkır, Zeleny sedimantasyon bakımından Eraybey çeşitleri en yüksek değerleri almıştır. Tane sertliği özelliği bakımından Bayraktar-2000 ve Gerek-79 çeşitleri yumuşak grupta, Tosunbey, Pehlivan, Konya-2002, Demir-2000 ve Ahmetağa çeşitleri sert grupta yer almışlardır. Morfolojik ve incelenen bazı kalite parametreleri bakımından değerlendirdiğimizde Karahan-99, Eraybey, Bozkır ve Pehlivan çeşitlerinin yüksek değer verdikleri ve Orta Anadolu Bölgesinde kuru koşullarda bu çeşitlerin verim ve kalite özelliklerinin iyi olacağı tahmin edilmektedir.

\section{Teşekkür}

Bu çalışma Seydi Aydoğan tarafından Selçuk Üniversitesi Fen Bilimleri Enstitüsü Tarla Bitkileri Anabilim Dalında yapılan yüksek lisans tezinin bir kısmını kapsamaktadır. Tezin yürütülmesinde destek sağlayan Bahri Dağdaş 
Uluslararası Tarımsal Araştırma Enstitüsü Müdürlüğüne katkılarından dolayı teşekkür ederiz.

\section{Kaynaklar}

Anonim, 2013. www.tuik.gov.tr/bitkiselapp /bitkisel. (Erişim tarihi: 24.09.2013)

Anonim, 2014. Jsl Syntax reference. SAS Institute JMP11., ISBN:978-1-62959-560-3

Anonim, 2015. www.uhk.org.tr

Anonymous, 2000. Approved methods of the american association of cereal chemistusa

Anonymous, 2009. Approvedmethodologies www. leco.com/resources/approved methods

Aydemir T., Barut, A., Yılmaz, K. ve Sezer, N., 2001. Yılı milli çeşit listesinde yer alan ekmeklik buğdayların bölgeler bazında verim ve kalite yönünden değerlendirilmesi. Türkiye IV. Tarla Bitkileri Kongresi, 17-21

Aydoğan S., Akçacık, A. G., Şahin, M. ve Yüksel, K., 2007. Ekmeklik buğday (T. aestivum L.) genotiplerinde verim ve bazı kalite özellikleri arasındaki ilişkiler. Tarla Bitkileri Merkez Araştırma Enstitüsü Dergisi, 16:(1-2):21-30 Ankara

Aydoğan S., Göçmen Akçacık, A., Şahin, M., Kaya, Y., Taner, S., Demir, B. ve Önmez, H., 2010. Ekmeklik buğday çeşitlerinin tane verimi, bazı kimyasal ve reolojik özellikleri üzerine bir araştırma. Bitkisel Araştırma Dergisi, 1-7 s, Konya

Aydoğan S., Göçmen Akçacık, A., Şahin, M., Önmez, H., Demir, B. ve Yakışır, E., 2013. Ekmeklik buğday çeşitlerinde fizikokimyasal ve reolojik özelliklerin belirlenmesi. Tarla Bitkileri Merkez Araştırma Enstitüsü Araştırma Dergisi, 22 (2): 74-85 s, Ankara

Dencic S., Kastori, R., Kobiljski, B. and Duggan, B., 2000. Evaluation of grain yield and its components in wheat cultivars and landracesunder near optimal and drought conditions, Euphytica, 113: 43-52

Elgün A, Türker $S$ ve Bilgiçli, N., 2001. Tahıl ve ürünlerinde analitik kalite kontrolü. Selçuk Üniversitesi Ziraat Fakültesi Gıda Mühendisliği. Konya Ticaret Borsası Yayın No:2 Konya

Ercan R. ve Bildik, E., 1993. Azotlu gübre uygulamasının ekmeklik buğday kalitesine etkisi. Gıda Dergisi, 18-3
Kınacı E. ve Dayıoğlu, R., 1998. Determination of drought resistant wheat genotypes and related morphological and physiological parameters under Central Anatolian conditions. Tübitak Projesi Sonuç Raporu. 62

Kimurto P., Kinyua, M. and Njoroge, J., 2004. Response of bread wheat genotypes to drought simulation under a mobile rain shelter in Kenya. African Crop Science Journal, 11(3): 225-234

Özturk A. ve Aydin, F., 2004. Effect of water stress at various growth stages on some quality characteristics of winter wheat. Journal of Agronomy and Crop Science, 190(2): 93-99

Öztürk A., 1999b. Kuraklığın kışlık buğdayın gelişmesi ve verimine etkisi. Agriculture and Forestry, 23: 531-540

Shamsi K., Petrosyan, M., Noor Mohammadi, G. and Haghparast, R. J., 2010. Evaluation of grain yield and its components in three bread wheat cultivars under drought stres. Animal and Plant Sci. 1117-1121

Subhani G. M. and Chowdhry, A.A., 2000. Correlation and path coefficient analysis an bread wheat under drought stres and normal conditions. Of Bio, 72-77

Şahin M., Göçmen Akçacık, A. ve Aydoğan, S., 2008. Orta anadolu kuru ve sulu koşulları için tescil edilmiş ekmeklik buğday çeşitlerinin verim ve bazı kalite özellikleri yönünden performanslarının belirlenmesi. Ülkesel Tahıl Sempozyumu 2-5 Haziran 2008 Konya, 390400

Şahin M., Göçmen Akçacık, A., Aydoğan, S., Demir, B., Önmez, H. ve Taner, S., 2013. Ekmeklik buğday ununda ekmek hacmi ile bazı fizikokimyasal ve reolojik özellikler arasındaki ilişkilerin tespiti. Tarla Bitkileri Merkez Araştırma Enstitüsü Dergisi, 2013, 22 (1): 13-19 s, Ankara

Tunca Z., 2012. Bazı buğday çeşitlerinin adaptasyon kabiliyeti, agronomik ve fizyolojik özelliklerinin belirlenmesi. Eskişehir Osmangazi Üniversitesi. Fen Bilimleri Enstitüsü, Tarla Bitkileri Anabilim Dalı (Yüksek Lisans Tezi)

Yürür N., Tosun, O., Eser, D. ve Geçit, H.H., 1981. Buğdayda ana sap verimi ile bazı karakterleri arasındaki ilişkiler. A.Ü. Z.F. Yayınları 755443. Bilimsel Araştırma ve İncelemeler 